\title{
Non-bank financial institutions and economic growth: Evidence from Africa's three largest economies
}

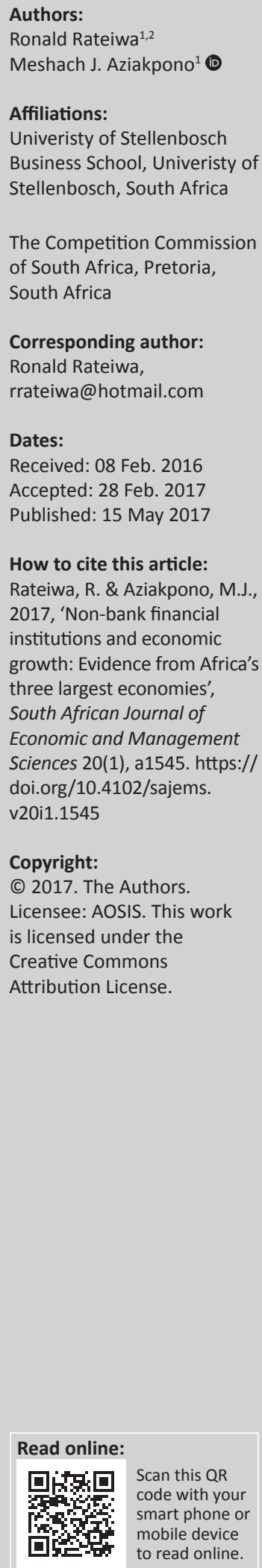

Background: In order for the post-2015 world development agenda - termed the sustainable development goals (SDGs) - to succeed, there is a pronounced need to ensure that available resources are used more effectively and additional financing is accessed from the private sector. Given that traditional bank lending has slowed down, the development of non-bank financing has become imperative. To this end, this article intends to empirically test the role of non-bank financial institutions (NBFIs) in stimulating economic growth.

Aim: The aim of this article is to empirically test the existence of a long-run equilibrium relationship between economic growth and the development of NBFIs, and the causality thereof.

Setting: The empirical assessment uses time-series data from Africa's three largest economies, namely, Egypt, Nigeria and South Africa, over the period 1971-2013.

Methods: This article uses the Johansen cointegration and vector error correction model within a country-specific setting.

Results: The results showed that the long-run relationship between NBFI development and economic growth is relatively stronger in Egypt and South Africa, than in Nigeria. Evidence in respect of Nigeria shows that such a relationship is weak. The nature of the relationship between NBFI development and economic growth in Egypt is positive and significant, and predominantly bidirectional. This suggests that a virtuous relationship between NBFIs and economic growth exists in Egypt. In South Africa, the relationship is positive and significant and predominantly runs from NBFI development to economic growth, implying a supplyleading phenomenon. In Nigeria, the results are weak and mixed.

Conclusion: The study concludes that in countries with more developed financial systems, the role of NBFIs and their importance to the economic growth process are more pronounced. Thus, there is need for developing policies targeted at developing the NBFI sector, given their potential to contribute to economic growth.

\section{Introduction}

In order for the post-2015 world development agenda - termed the sustainable development goals - to succeed, there is a pronounced need to ensure that available resources are used more effectively and that additional financing be accessed from the private sector (International Monetary Fund 2015a). However, given the lingering fragility of financial markets in the wake of the recent global financial crisis, the availability of long-term financing required to support productive investment has been constrained (World Bank 2015a). Specifically, traditional bank lending has slowed down substantially as banks recover from the financial crisis and adjust to tighter regulatory controls - mostly emanating from the stricter Basel III capital and liquidity requirements. To this end, the development of non-bank financing has become imperative (World Bank 2013a). This article accordingly explores the role of non-bank financial institutions (NBFIs) as a source of long-term funding. In doing so, the article investigates the linkage between NBFI development and economic growth (the finance-growth nexus) using time-series data from Africa's three largest economies (Egypt, Nigeria and South Africa) over the period 1971 to 2013.

Non-bank financial institutions are financial institutions that do not have a full banking licence and thus cannot take deposits. However, they both compete with and complement traditional banking institutions by providing alternative financial services such as contractual savings (pension funds and insurance companies), investment intermediaries (finance companies, mutual funds and money market funds), microloan organisations and venture capitalists (Mishkin 2007; World Bank 2015c). The three main categories of NBFIs in Egypt 
(Egyptian Financial Supervisory Authority 2017), Nigeria (Ndugbu et al. 2015) and South Africa (Faure et al. 2006) are insurance companies, pension funds and investment institutions.

A cursory look at Figure 1 suggests a strong and positive relationship between the growth in NBFI assets and gross domestic product (GDP) trend in the three countries. Thus, this study is motivated to explore the actual relationship that exists between NBFI development and economic growth, using rigorous econometric methods.

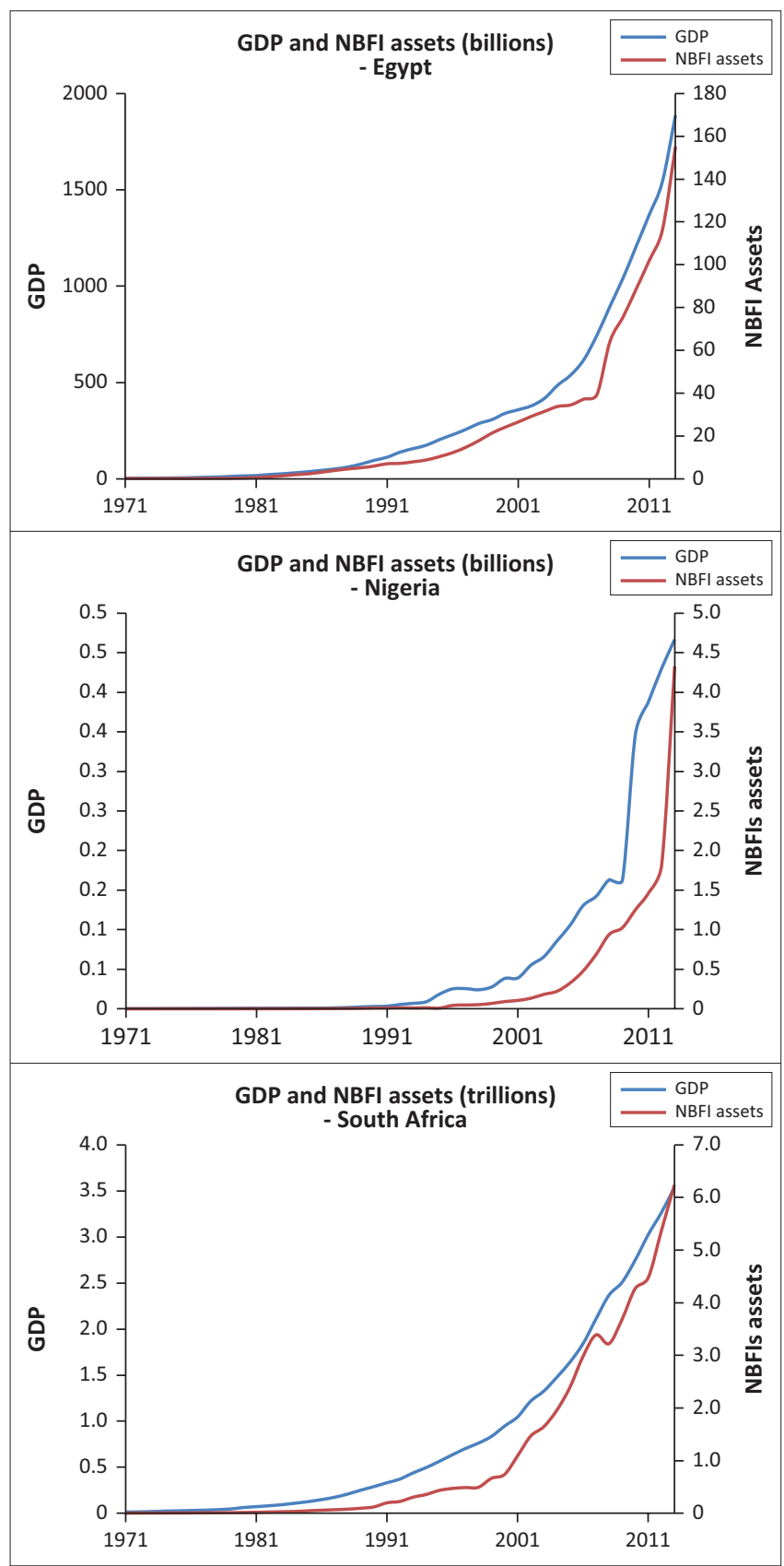

Source: World Bank, 2015d, World Development Indicators, World Bank, Washington, DC; Central Bank of Egypt, 2015, Publications, accessed on 16 June 2015 from http://www.cbe.org. eg/en/EconomicResearch/Publications/Pages/MonthlyStatisticaclBulletin.aspx; Central Bank of Nigeria, 2015, Data and Statistics, accessed on 15 June 2015 from https://www.cbn.gov.ng/ documents/data.asp; South African Reserve Bank, 2015, Online Statistics, accessed on 16 June 2015 from https://www.resbank.co.za/Research/Statistics/Pages/OnlineDownloadFacility.aspx FIGURE 1: Co-movement of non-bank financial institution assets and gross domestic product for Egypt, Nigeria and South Africa: 1971-2013.
The recent global financial crisis clearly demonstrates that if the development of NBFIs is too rapid and is not properly regulated and monitored, it may create conditions susceptible to a financial crisis. Specifically, Liang and Reichert (2012) warned that if NBFIs are not properly regulated, they allow excessive risk appetite, which may have disastrous consequences for both the financial sector and the real economy. This was further emphasised by the shadow banking monitoring report at the end of 2015 (Financial Stability Board 2015). The report argued that although NBFIs contribute to the financing of real economy, they can become a source of systemic risk when they perform 'bank-like' functions and also when their interconnectedness with banks is strong.

Furthermore, recent studies raise very profound questions about the finance-growth debate - especially in Africa where both financial development (FD) and economic growth have remained subdued - leaving the debate unresolved. Specifically, recent studies found that the relationship between FD and economic growth is weakening in both developed and developing countries and that 'financial depth is no-longer a significant determinant of long-run economic growth' (Demetriades \& Rousseau 2015; Rousseau \& Wachtel 2011). In Africa, Demetriades and James (2011:1) argued that 'at worst' the relationship between FD and long-run economic growth does not exist in Africa.

In respect of the countries under scrutiny, our survey of literature revealed a dearth of studies investigating the impact of NBFIs on economic growth. For the few that are available, some focused only on a certain component of NBFIs, such as pension funds, which may have the effect of underestimating the influence of NBFIs on economic growth in these countries. Other studies focused on the impact of regulation on stability and performance of NBFIs (Ofoeda Gariba \& Amoah 2016), while some others focused on the impact of NBFIs on access to credit (Kabia, Conteh \& Jalloh 2015) and investment in certain sectors (Hamdi 2015).

However, given the potential of NBFIs to fund long-term growth, and risks arising from the linkages between NBFIs and other financial institutions, and the conflicting results on the relationship between FD especially in Africa, this article accordingly uses country-specific time-series econometric techniques to re-investigate whether or not NBFIs - as a source of long-term funding - matter for economic growth, and if so, how.

The three hypotheses to be tested are whether the relationship between NBFIs and economic growth is (1) demandfollowing, (2) supply-leading (Patrick 1966) or (3) a simultaneous two-way causality, which can be either a vicious or a virtuous cycle (Berthelemy \& Varoudakis 1996). The analysis in this article will be carried out using the Johansen cointegration and error correction modelling techniques within a country-specific setting. Analysis in this article is restricted to the aggregate figures of NBFIs because of the unavailability of data for the different categories of NBFIs, 
such as pension funds, insurance companies and mutual funds for all the three countries over the relevant period.

The choice of these three countries, Egypt, Nigeria and South Africa, is based on their significance to Africa's economy and its financial system (KPMG Africa Limited 2013; World Bank 2015b). In addition, these three countries comprise approximately $60 \%$ of all infrastructure investments in Africa, which are predominantly funded through NBFIs (Mo Ibrahim Foundation 2013). Lastly, these countries have the oldest capital markets in Africa, thus implying that they have data available over a period longer than other African countries. Thus, studying these countries will not only provide useful insight for policy in these three countries but also in the rest of African countries and other African economies.

The remainder of this article is organised as follows: The 'NBFI development and economic growth' section provides the theoretical framework linking NBFI development to economic growth. The 'Methodology' section presents the methodology applied in this study. The 'Estimation results' section presents the empirical results and the 'Conclusion' section concludes the article.

\section{Non-bank financial institution development and economic growth}

The literature shows that the linkage between NBFI development and economic growth can be both direct and indirect (Alderman \& Yemtsov 2013; Davis \& Hu 2008; Haiss \& Sumegi 2008; Holzmann 1997; Liang \& Reichert 2012; Meng \& Pfau 2010; Nassr \& Wehinger 2014; Sufian \& Majid 2009; Vittas 1997). It can be direct in the sense that NBFIs can directly influence savings, investment, risk allocation and total factor productivity, thus enhancing economic growth.

On the contrary, the linkage can be indirect through the influence of NBFIs on the development of banks and capital (stock and bond) markets, which, in turn, influences economic growth (Haiss \& Sumegi 2008; Meng \& Pfau 2010; Sufian \& Majid 2009). However, if the growth in the volume of loanable funds is too rapid and is not properly regulated and monitored, it may create conditions susceptible to a financial crisis. Liang and Reichert (2012) accordingly warn that if NBFIs are not properly regulated, they allow excessive risk appetite which may have disastrous consequences for both the financial sector and the economy.

However, literature suggests that the relationship between FD (using various indicators) and economic growth is by no means simple or apparent. Patrick (1966) proposed the demand-following or supply-leading hypotheses. A demandfollowing scenario implies that causality runs from economic growth to FD. In this case, NBFIs would develop in response to the demand for their services by the real economy. Contrastingly, however, a supply-leading scenario arises when causality runs from FD to economic growth. Thus, the development of NBFIs precedes the demand for its services by the real economy. The argument is that FD leads to economic growth by facilitating the mobilisation of savings and efficient allocation of capital (Levine 2004). Therefore, the a priori expectation is that the development of NBFIs (in this case) positively influences economic growth. An opposing view, however, is that FD eliminates liquidity constraints and thus reduces the incentive to save, which may further inhibit economic growth (Aziakpono 2011; Levine and Servos 1998).

Lastly, the causality between FD and economic growth can also take the form of a simultaneous two-way causality. The simultaneous two-way causality can be either a vicious or a virtuous cycle (Berthelemy and Varoudakis 1996). A vicious cycle occurs when economic growth is too low; so low that it prevents the development of the financial sector, which, in turn, prevents economic growth. In this instance, the longrun coefficient of NBFI development on economic growth (or vice-versa) is expected to be negative. On the contrary, a virtuous cycle arises when a high level of economic growth supports the development of the financial sector, which, in turn, stimulates further economic growth. Thus, the long-run effect of NBFI development on economic growth (or viceversa) is expected to be positive.

\section{Empirical evidence on non-bank financial institution development and economic growth}

A cross-reading of the literature revealed that very few studies have investigated the effect of NBFI development on economic growth within a specific country setting. Only two studies focused on Nigeria. No country-specific studies were found in respect of Egypt and South Africa. The two studies for Nigeria (Ndugbu et al. 2015; Osuala \& Odunze 2014) covered the periods 1996-2010 and 1992-2012, respectively, using different indicators for finance companies, insurance companies and discount houses. Both studies only found a positive relationship between assets of insurance companies and economic growth, while there was no evidence of any relationship between assets of finance companies and discount houses, and economic growth. Osuala and Odunze (2014) used the autoregressive distributive lag (ARDL) model, while Ndugbu et al. (2015) used the ordinary least squares methodology in their study. This article uses a different econometric approach (i.e. the Johansen cointegration and vector error correction model) covering a longer period (1971-2013) to re-investigate the relationship between NBFI activity and economic growth.

Another empirical study including African countries showed that if NBFIs facilitate excessive risk appetite, their influence on economic growth can be negative. More specifically, a cross-country panel study which included Egypt, Nigeria and South Africa found a negative relationship between NBFI development and economic growth for both developed and emerging market countries (Liang and Reichert 2012). A possible reason provided for their finding was that NBFIs are not properly regulated; hence, they allow excessive risk appetite, which may have disastrous consequences for both the financial sector and the economy. 
Other studies related to the intermediary functions of NBFIs but not directly investigating the link between NBFIs and economic growth include Kabia et al. (2015), Hamdi (2015) and Ofoeda et al. (2016). Kabia et al. (2015) relied on data from a case study of 150 respondents in Sierra Leone to conclude that NBFIs helped increase access to finance by poor communities, thereby reducing poverty. The data used in the analysis covered the period 2001-2005. In a report based on evidence obtained from Sudan, Hamdi (2015) argued that because of the 'smallness' of the NBFIs and tight regulatory controls by the Central Bank in that country, there has rarely been any investments by NBFIs into extractive industries such as mining, oil and gas. Lastly, Ofoeda et al. (2016) relied on evidence from Ghana over the period 20062010 to conclude that effective regulation enhances the stability and profitability of NBFIs in that country. Given the dearth of studies focusing on the impact of NBFI development on economic growth in Africa, and the conflicting results from the previous studies, it becomes imperative that the relationship be reassessed using time-series evidence within a country-specific setting. This approach will minimise heterogeneity of country characteristics from influencing the results, thus improving the reliability of conclusions obtained therefrom. In the following section, we present the methodological framework used in assessing the relationship between NBFI development and economic growth.

\section{Methodology Model specification}

In this article, we adopt the traditional approach to investigate the finance-growth nexus, according to which we regress economic growth $(\mathrm{Y})$ on FD together with other control variables, that is, $\mathrm{Y}=\mathrm{f}$ (FD, control variables) (Aziakpono 2008; Levine 2004). Economic growth is proxied by log of per capita real GDP. Our decision to use log of per capita real GDP is consistent with most time-series studies, whereas crosscountry studies use the growth rate of per capital GDP (Arestis, Luintelc \& Luintel 2010; Yeh, Huang \& Lin 2013). As indicated above, FD will be proxied by NBFIs (assets of NBFIs expressed as a percentage of GDP), because it is the objective of this study to establish the importance of NBFIs in the finance-growth debate.

This article uses a trivariate model following the approach used by Luintel and Khan (1999), Aziakpono (2008) and Arestis et al. (2010). In the trivariate model, one control variable is added at a time. Economic growth and NBFI development variables remain constant in the model because they are the variables of interest.

The main advantage of using this approach is that adding one variable at a time helps to address the possible misspecification problem inherent in a bivariate model, which may result in erroneous causal inferences (Luintel \& Khan 1999). Secondly, it helps to test the robustness of the long-run relationship between economic growth and NBFI development, and how such long-run relationship is affected by the control variable used (Aziakpono 2008).

\section{Econometric procedure}

To empirically examine this relationship, this study uses the Johansen cointegration and vector error correction model within a country-specific setting. This approach provides a framework for testing the existence of a long-run equilibrium relationship between $\mathrm{Y}$ and FD, and the causality thereof. As explained above, the three hypotheses to be tested are whether the relationship between NBFIs and economic growth is: (1) demand-following, (2) supply-leading (Patrick 1966) or (3) a simultaneous two-way causality, which can be either a vicious or a virtuous cycle (Berthelemy \& Varoudakis 1996).

Based on the approach by Aziakpono (2008) and Arestis et al. (2010), the multivariate vector error correction model with $\mathrm{k}$ lags can be expressed as follows:

$$
\Delta X_{t}=\prod X_{t-1}+\sum_{t=1}^{k} \Gamma \mathrm{i} \Delta X_{t-1}+\varepsilon_{k t}
$$

where $X_{t}=f(Y, F D$, control variable $)$ is a $3 \times 1$ vector. The variables are integrated of order 1 , that is, $\mathrm{I}(1) . \Delta \mathrm{X}_{\mathrm{t}}$ is $\mathrm{I}(0)$; $\Gamma^{\mathrm{i}}$ represents $3 \times 3$ short-run coefficient matrices and $\varepsilon_{\mathrm{kt}}$ is the error term and is normally and independently distributed.

The full rank of $\prod_{i}$ matrix is $r$. In a trivariate model (where $n=3)$, if $r=3$, then the variables $X_{t}$ are $\mathrm{I}(0)$. However, if the rank of the $\Pi$ matrix is zero, then there are no cointegrating relationships between the variables. The $\Pi$ matrix can also have a reduced rank in the order of $r \leq$ $(n-1)$. Thus, in a trivariate model, two reduced ranks are possible: $r=1$ (one cointegrating vector) and $r=2$ (two cointegrating vectors).

In carrying out the analysis, only models that satisfied the serial correlation and heteroscedasticity tests, with a certain level of explanatory power, were reported. Specifically, only models with adjusted $R^{2}$ values greater than 30\%, are reported. This is to ensure that the model has a relatively high explanatory power and good fit.

\section{Data and sources}

Data used in estimating the model are annual and cover the period 1971-2013, but were not available for the entire period for some of the variables. The period of study was chosen solely because of data limitations; a problem which is generally associated with African countries. Data were obtained from the World Development Indicators (WDI), Global Development Finance Database (GDF), International Financial Statistics (IFS), United Nations Statistics (UN Stats) and the central banks of Egypt, Nigeria and South Africa. The description of variables used in the analysis is presented in Table 1.

The development in NBFIs in the selected countries is shown in Figure 2. 


\section{Ethical considerations}

We believe that this work complies with all ethical requirements for academic work.

\section{Estimation results}

This section presents and discusses the results. The results are presented in four sections: (1) results from the unit root test, (2) cointegration results, (3) weak exogeneity test results and (4) the long-run relationship between NBFI development and economic growth.

\section{Unit root test results}

In order to test the stationarity of the variables, we use two test methods, namely the Augmented Dickey Fuller and the breakpoint unit root test as a confirmatory test. For Egypt and Nigeria, the unit root and breakpoint unit root tests results show that most of the variables are first difference stationary, that is, I(1) series. The only exception was oil rents and interest rate spread that were stationary at level for both countries. Similarly, for South Africa, the unit root tests results also show that most of the variables were I(1) series. The only variables that were level stationary are lending and deposit rates, spread, exports, imports and net taxes.

The next step is to carry out the cointegration test and the vector error correction model estimation to determine whether or not a long-run relationship exists among the variables.

\section{Cointegration}

Cointegration suggests the existence of a long-run equilibrium relationship between economic variables (Brooks 2014; Engle \& Granger 1987; Geda, Ngungu, \& Zerfu 2012; Kennedy 2003). We use the Johansen cointegration technique

TABLE 1: Description of control variables.

\begin{tabular}{|c|c|c|c|c|}
\hline \multirow[t]{2}{*}{ Variable } & \multirow[t]{2}{*}{ Definition } & \multicolumn{3}{|c|}{ Country } \\
\hline & & Egypt & Nigeria & South Africa \\
\hline Y & Real GDP per capita. & $1971-2013$ & $1971-2013$ & $1971-2013$ \\
\hline Agric & $\begin{array}{l}\text { Agriculture corresponds to the International Scientific Industrial Classification divisions } 1-5 \text { and } \\
\text { includes forestry, hunting and fishing, as well as cultivation of crops and livestock production. }\end{array}$ & 1971-2013 & 1981-2013 & $1971-2013$ \\
\hline $\mathrm{CPI}$ & Consumer Price Index (2010 as base year). & 1971-2013 & $1971-2013$ & $1971-2013$ \\
\hline DepositR & Deposit interest rate is the rate offered by commercial banks on 3-month deposits. & $1976-2013$ & 1971-2013 & $1977-2013$ \\
\hline Elec & $\begin{array}{l}\text { Electric power consumption measures the production of power plants and combined heat and } \\
\text { power plants less transmission, distribution and transformation losses and own use by heat and } \\
\text { power plants. }\end{array}$ & 1971-2011 & $1971-2011$ & $1971-2011$ \\
\hline ElecPecapita & Electric power consumption per capita. & 1971-2011 & $1971-2011$ & 1971-2011 \\
\hline ERav & National Currency per US dollar, period average. & $1971-2013$ & $1971-2013$ & $1971-2013$ \\
\hline ERend & National Currency per US dollar, end of period. & 1971-2013 & 1971-2013 & $1971-2013$ \\
\hline Exports & $\begin{array}{l}\text { Exports of goods and services represent the value of all goods and other market services } \\
\text { provided to the rest of the world. }\end{array}$ & $1971-2013$ & $1971-2013$ & 1971-2013 \\
\hline GasRent & $\begin{array}{l}\text { Natural gas rents are the difference between the value of natural gas production at world prices } \\
\text { and total costs of production. }\end{array}$ & $1971-2013$ & $1971-2013$ & 1971-2013 \\
\hline GCF & $\begin{array}{l}\text { Gross capital formation (formerly gross domestic investment) consists of outlays on additions to } \\
\text { the fixed assets of the economy plus net changes in the level of inventories. }\end{array}$ & $1971-2013$ & $1971-2013$ & $1971-2013$ \\
\hline GvtCons & $\begin{array}{l}\text { Government consumption - final consumption expenditure includes all government current } \\
\text { expenditures for purchases of goods and services (including compensation of employees). }\end{array}$ & $1971-2013$ & $1971-2013$ & $1971-2013$ \\
\hline Imports & $\begin{array}{l}\text { Imports of goods and services represent the value of all goods and other market services } \\
\text { received from the rest of the world. }\end{array}$ & $1971-2013$ & $1971-2013$ & $1971-2013$ \\
\hline Industri & It comprises value added in mining, manufacturing, construction, electricity, water and gas. & 1971-2013 & 1981-2013 & $1971-2013$ \\
\hline LendingR & Lending rate is the rate charged by banks on loans to the private sector. & $1976-2013$ & $1971-2013$ & $1971-2013$ \\
\hline Mrents & $\begin{array}{l}\text { Mineral rents are the difference between the value of production for a stock of minerals at world } \\
\text { prices and their total costs of production. }\end{array}$ & 1971-2013 & 1971-2013 & $1971-2013$ \\
\hline NEREExRate & Nominal effective exchange rate. & & 1979-2013 & 1979-2013 \\
\hline NetTaxes & $\begin{array}{l}\text { Net taxes on products (net indirect taxes) are the sum of product taxes less subsidies. Product } \\
\text { taxes are those taxes payable by producers that relate to the production, sale, purchase or use of } \\
\text { the goods and services. }\end{array}$ & $1971-2013$ & 1981-2013 & 1971-2013 \\
\hline OilRent & $\begin{array}{l}\text { Oil rents - the difference between the value of crude oil production at world prices and total } \\
\text { costs of production as a percentage of GDP. }\end{array}$ & $1971-2013$ & $1971-2013$ & 1971-2013 \\
\hline OPP & Openness to trade is the total value of exports and imports, expressed as a percentage of GDP. & $1971-2013$ & $1971-2013$ & $1971-2013$ \\
\hline PDensity & Population density is mid-year population divided by land area in square kilometres. & $1971-2013$ & $1971-2013$ & 1971-2013 \\
\hline Pop & Number of people in a particular country. & $1971-2013$ & $1971-2013$ & 1971-2013 \\
\hline Spread & It is the difference between the deposit and the lending rates. & $1976-2013$ & $1971-2013$ & 1977-2013 \\
\hline Tel & $\begin{array}{l}\text { Telephone lines are fixed telephone lines that connect a subscriber's terminal equipment to the } \\
\text { public switched telephone network and that have a port on a telephone exchange. Integrated } \\
\text { services digital network channels and fixed wireless subscribers are included. }\end{array}$ & $1975-2013$ & $1981-2013$ & $1971-2013$ \\
\hline Tel100 & Telephone lines per every 100 people. & $1975-2013$ & $1981-2013$ & $1971-2013$ \\
\hline UrbanPop & $\begin{array}{l}\text { Population in urban agglomerations of more than } 1 \text { million is the country's population living in } \\
\text { metropolitan areas that in } 2000 \text { had a population of more than } 1 \text { million people. }\end{array}$ & $1971-2013$ & $1971-2013$ & $1971-2013$ \\
\hline
\end{tabular}

GDP, gross domestic product; Y, economic growth; CPI, consumer price index; OPP, openness to trade; GCF, gross capital formation; DepositR, deposit rate; Elec, electric power consumption; ElecPecapita, electric power consumption per capita; ERav, period average national currency exchange rate per US dollar; ERend, end period national currency exchange rate per US dollar; GvtCons, government consumption; Industri, industrial output; LendingR, lending rate; Mrents, mineral rents; NEREExRate, nominal effective exchange rate; PDensity, population density per square kilometre; Pop, number of people in a country; Spread, interest rate spread; Tel, number of telephone lines that are connected; Tel100, number of telephone lines per 100 people; UrbanPop, urban population.

Source: World Bank, 2015d, World Development Indicators, World Bank, Washington, DC; World Bank, 2013b, Global Development Finance Database, World Bank, Washington, DC; International Monetary Fund, 2015b, International Financial Statistics, IMF, Washington, DC; United Nations Statistics, 2015, International Trade Statistics Yearbook, United Nations Publication, New York 


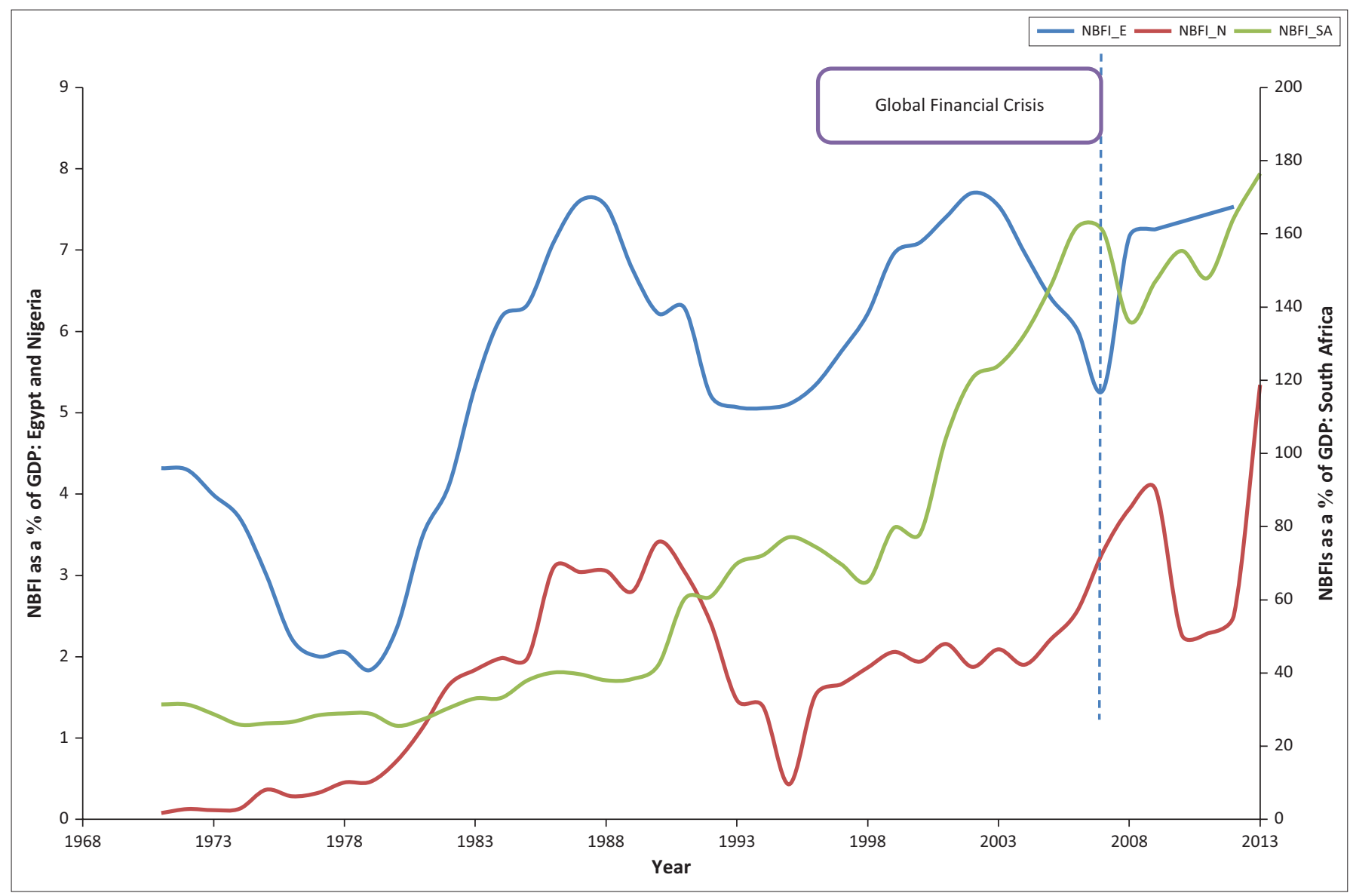

Source: World Bank, 2013b, Global Development Finance Database, World Bank, Washington, DC; Central Bank of Egypt, 2015, Publications, accessed on 16 June 2015 from http://www.cbe.org. eg/en/EconomicResearch/Publications/Pages/MonthlyStatisticaclBulletin.aspx; Central Bank of Nigeria, 2015, Data and Statistics, accessed on 15 June 2015 from https://www.cbn.gov.ng/ documents/data.asp; South African Reserve Bank, 2015, Online Statistics, accessed on 16 June 2015 from https://www.resbank.co.za/Research/Statistics/Pages/OnlineDownloadFacility.aspx

FIGURE 2: Assets of non-bank financial institutions expressed as percentage of gross domestic product for Egypt, Nigeria and South Africa: $1971-2013$.

to test for cointegration. Table 2 presents the cointegration test results. In the table, ' $\mathrm{K}$ ' indicates the vector autoregression order that produces a white noise residual and ' $\mathrm{A}$ ' indicates the deterministic trend assumption for each particular model. The cointegration test results are presented in Table 2.

Of the 22 models estimated for each country, the trace test and the max eigenvalue test show that there is a cointegration between NBFI development and economic growth in eight models each for Egypt and South Africa. However, only two models show evidence of cointegration between these variables in Nigeria. This clearly shows that in Nigeria, there is a weak relationship between NBFI development and economic growth. The relationship between NBFIs and economic growth in Egypt and South Africa is relatively stronger compared with that in Nigeria.

\section{Causality between non-bank financial institution development and economic growth}

Given the conflicting views in respect of the causal link between FD and economic growth, what prevails within each particular setting becomes an empirical issue. If cointegration exists, there must be causality from at least one of the variable to the other. In this article, we use the weak exogeneity approach to test the direction of causality between NBFI development and economic growth. The nature of the causal effect (i.e. whether positive or negative) is presented in Table 4 in the section below. The weak exogeneity results and the direction of causality thereof, are reported in Table 3. Table 3 reports the chi-square statistic and the probability value of the test. Specifically, it presents three null hypotheses: (1) the two-way causality between economic growth and NBFI development, (2) causality running from economic growth to NBFI development and (3) causality running from NBFI development to economic growth. A 'Yes' indicates that the null hypothesis could not be rejected, whereas a 'No' indicates that the null hypothesis is rejected. The results are discussed separately for each country.

\section{Egypt}

Results presented in Table 3 show a predominantly two-way causality between economic growth and NBFI development in Egypt. Only two models reported causality running from NBFIs to economic growth, only without a reverse causality. This suggests that, at least in Egypt, the relationship between NBFI development and economic growth would be a virtuous cycle if the two systems positively and significantly influence each other. In this case, the long-run coefficients are expected to be positive. However, if the long-run coefficients are negative, it implies that the relationship between NBFI development and economic growth in Egypt follows a vicious cycle. Thus, the low level of economic growth leads to underdevelopment of NBFIs, which, in turn, hinders economic growth. 
TABLE 2: Cointegration results: Egypt, Nigeria and South Africa.

\begin{tabular}{|c|c|c|c|c|c|c|c|c|c|c|c|c|c|c|c|c|}
\hline \multirow[t]{3}{*}{ Country } & \multirow{3}{*}{$\begin{array}{l}\text { Control } \\
\text { variable }\end{array}$} & \multirow[t]{3}{*}{ Obs } & \multirow[t]{3}{*}{$\mathbf{K}$} & \multirow[t]{3}{*}{$A$} & \multicolumn{6}{|c|}{ Trace statistic } & \multicolumn{6}{|c|}{ Max eigenvalue } \\
\hline & & & & & \multicolumn{2}{|c|}{$r<0$} & \multicolumn{2}{|c|}{$r<1$} & \multicolumn{2}{|c|}{$r<2$} & \multicolumn{2}{|c|}{$r<0$} & \multicolumn{2}{|c|}{$r<1$} & \multicolumn{2}{|c|}{$r<2$} \\
\hline & & & & & T-Statistic & Probability & T-Statistic & Probability & T-Statistic & Probability & T-Statistic & Probability & T-Statistic & Probability & T-Statistic & Probability \\
\hline \multirow[t]{8}{*}{ Egypt } & GasRents & 36 & 5 & 3 & 36.30 & 0.00 & 9.79 & 0.30 & 0.28 & 0.60 & 26.51 & 0.01 & 9.51 & 0.25 & 0.28 & 0.60 \\
\hline & Industr & 36 & 5 & 2 & 49.14 & 0.00 & 17.91 & 0.10 & 6.33 & 0.17 & 31.23 & 0.00 & 11.59 & 0.21 & 6.32 & 0.17 \\
\hline & LendingR & 32 & 4 & 4 & 55.88 & 0.00 & 23.06 & 0.11 & 4.35 & 0.70 & 32.82 & 0.01 & 18.71 & 0.06 & 4.35 & 0.69 \\
\hline & NetTaxes & 38 & 3 & 4 & 56.74 & 0.00 & 21.51 & 0.16 & 5.63 & 0.51 & 35.23 & 0.00 & 15.88 & 0.15 & 5.63 & 0.51 \\
\hline & OilRents & 38 & 3 & 3 & 41.02 & 0.00 & 14.69 & 0.07 & 2.14 & 0.14 & 26.33 & 0.01 & 12.56 & 0.09 & 2.14 & 0.14 \\
\hline & OPP & 36 & 5 & 2 & 42.72 & 0.00 & 20.09 & 0.05 & 8.87 & 0.06 & 22.62 & 0.05 & 11.22 & 0.24 & 8.87 & 0.06 \\
\hline & Tel & 31 & 2 & 2 & 36.36 & 0.03 & 11.13 & 0.53 & 2.27 & 0.72 & 25.24 & 0.02 & 8.86 & 0.45 & 2.27 & 0.72 \\
\hline & Tel100 & 31 & 2 & 2 & 36.98 & 0.03 & 11.09 & 0.54 & 2.44 & 0.69 & 25.90 & 0.02 & 8.65 & 0.47 & 2.44 & 0.69 \\
\hline \multirow[t]{2}{*}{ Nigeria } & GasRents & 40 & 2 & 4 & 44.30 & 0.03 & 14.97 & 0.58 & 5.03 & 0.59 & 29.34 & 0.02 & 9.94 & 0.63 & 5.03 & 0.59 \\
\hline & UrbanPop & 38 & 4 & 4 & 46.89 & 0.02 & 18.74 & 0.30 & 6.35 & 0.42 & 28.16 & 0.02 & 12.38 & 0.38 & 6.35 & 0.42 \\
\hline \multirow{8}{*}{$\begin{array}{l}\text { South } \\
\text { Africa }\end{array}$} & $\mathrm{CPI}$ & 38 & 4 & 4 & 59.36 & 0.00 & 20.98 & 0.18 & 9.47 & 0.15 & 38.38 & 0.00 & 11.52 & 0.46 & 9.47 & 0.15 \\
\hline & DepositR & 34 & 2 & 4 & 48.87 & 0.01 & 19.43 & 0.26 & 8.44 & 0.22 & 29.45 & 0.02 & 10.99 & 0.51 & 8.44 & 0.22 \\
\hline & Exports & 39 & 3 & 4 & 48.27 & 0.01 & 16.67 & 0.44 & 3.30 & 0.84 & 31.60 & 0.01 & 13.37 & 0.30 & 3.30 & 0.84 \\
\hline & GCF & 34 & 8 & 3 & 80.40 & 0.00 & 13.77 & 0.09 & 1.74 & 0.19 & 66.64 & 0.00 & 12.03 & 0.11 & 1.74 & 0.19 \\
\hline & GvtCons & 40 & 2 & 2 & 37.58 & 0.03 & 13.12 & 0.35 & 5.49 & 0.23 & 24.47 & 0.02 & 7.63 & 0.59 & 5.49 & 0.23 \\
\hline & Imports & 38 & 4 & 3 & 42.59 & 0.00 & 14.75 & 0.06 & 0.54 & 0.46 & 27.85 & 0.01 & 14.21 & 0.05 & 0.54 & 0.46 \\
\hline & NetTaxes & 37 & 5 & 4 & 50.81 & 0.01 & 24.33 & 0.08 & 8.85 & 0.19 & 26.49 & 0.04 & 15.48 & 0.17 & 8.85 & 0.19 \\
\hline & Spread & 32 & 4 & 2 & 37.18 & 0.03 & 12.94 & 0.37 & 6.13 & 0.18 & 24.25 & 0.03 & 6.81 & 0.69 & 6.13 & 0.18 \\
\hline
\end{tabular}

$\mathrm{CPI}$, consumer price index; GCF, gross capital formation; OPP, openness to trade; Obs, observations; K, number of lags; A, deterministic assumption used for the estimation; Industr, industria output; LendingR, lending rate; Tel, number of telephone line connections; Tel100, number of telephone line connections per 100 people; UrbanPop, urban population; DepositR, deposit rate; GvtCons, government consumption; Spread, interest rate spread.

Note: See Table 1 for definition of control variables.

TABLE 3: Weak exogeneity test for Egypt, Nigeria and South Africa.

\begin{tabular}{|c|c|c|c|c|c|c|c|c|}
\hline \multirow[b]{3}{*}{ Country } & \multirow[b]{3}{*}{ Control variable } & \multicolumn{4}{|c|}{ Weak exogeneity test } & \multicolumn{3}{|c|}{ Causality between Y and FD null hypothesis } \\
\hline & & \multicolumn{2}{|c|}{$Y$} & \multicolumn{2}{|c|}{ NBFI } & \multirow[b]{2}{*}{$\mathrm{Y} \leftrightarrow \mathrm{NFBI}$} & \multirow[b]{2}{*}{$\mathrm{Y} \rightarrow \mathrm{NBFI}$} & \multirow[b]{2}{*}{$\mathrm{Y} \leftarrow \mathrm{NBFI}$} \\
\hline & & Chi-square & Probability & Chi-square & Probability & & & \\
\hline \multirow[t]{8}{*}{ Egypt } & GasRents & 17.10 & 0.00 & 5.53 & 0.02 & Yes & Yes & Yes \\
\hline & Industr & 16.27 & 0.00 & 3.06 & 0.08 & Yes & Yes & Yes \\
\hline & Lending $\mathrm{R}$ & 4.12 & 0.04 & 9.69 & 0.02 & Yes & Yes & Yes \\
\hline & NetTaxes & 3.56 & 0.06 & 3.31 & 0.07 & Yes & Yes & Yes \\
\hline & OilRents & 3.81 & 0.05 & 1.22 & 0.27 & No & No & Yes \\
\hline & OPP & 4.69 & 0.03 & 0.02 & 0.88 & No & No & Yes \\
\hline & Tel & 16.26 & 0.00 & 12.63 & 0.00 & Yes & Yes & Yes \\
\hline & Tel100 & 16.25 & 0.00 & 12.42 & 0.00 & Yes & Yes & Yes \\
\hline \multirow[t]{2}{*}{ Nigeria } & GasRents & 2.70 & 0.10 & 5.26 & 0.02 & No & Yes & No \\
\hline & UrbanPop & 6.56 & 0.01 & 1.55 & 0.21 & No & No & Yes \\
\hline \multirow[t]{8}{*}{ South Africa } & $\mathrm{CPI}$ & 5.12 & 0.02 & 0.31 & 0.58 & No & No & Yes \\
\hline & DepositR & 5.62 & 0.02 & 0.27 & 0.60 & No & No & Yes \\
\hline & Exports & 4.10 & 0.04 & 0.51 & 0.48 & No & No & Yes \\
\hline & GCF & 3.16 & 0.08 & 14.50 & 0.00 & Yes & Yes & Yes \\
\hline & GvtCons & 5.11 & 0.02 & 0.01 & 0.92 & No & No & Yes \\
\hline & Imports & 3.55 & 0.06 & 0.55 & 0.46 & No & No & Yes \\
\hline & NetTaxes & 3.00 & 0.08 & 4.97 & 0.03 & Yes & Yes & Yes \\
\hline & Spread & 2.95 & 0.09 & 0.54 & 0.46 & No & No & Yes \\
\hline
\end{tabular}

CPI, consumer price index; GCF, gross capital formation; OPP, openness to trade; NBFI, non-bank financial institution; Y, economic growth; Industr, industrial output; LendingR, lending rate; Tel, number of telephone line connections; Tel100, number of telephone line connections per 100 people; UrbanPop, urban population; DepositR, deposit rate; GvtCons, government consumption; Spread, interest arte spread.

Note: 'Yes' indicates the null hypothesis cannot be rejected, while a 'No' indicates that the null hypothesis is rejected.

\section{Nigeria}

With regard to Nigeria, evidence of causality between NBFI development and economic growth is both weak and mixed. One of the two models reported shows that the direction of causality runs from economic growth to NBFI development, while the other one shows causality in the opposite direction.

\section{South Africa}

The weak exogeneity test results presented in Table 3 show that causality between NBFI development and economic growth in South Africa predominantly runs from NBFI development to economic growth. This suggests that the relationship is likely to be supply-leading, whereby the NBFIs create financial products required by the real economy in advance, thus facilitating economic growth.

The concomitant question that follows is: What is the nature (direction and significance) of the causal effect between NBFI development and economic growth? We present our findings in respect of the nature of causal effect in the following section. 
TABLE 4: Long-run parameters of models with causality running from non-bank financial institutions to economic growth

\begin{tabular}{|c|c|c|c|c|c|c|}
\hline \multirow[t]{2}{*}{ Country } & \multirow[t]{2}{*}{ Control variable } & \multicolumn{2}{|c|}{ LR coefficient of NBFI on $Y$} & \multicolumn{2}{|c|}{ ECM } & \multirow[t]{2}{*}{$Y \leftarrow N B F I$ (Sing of effect) } \\
\hline & & Coefficient & T-Statistic & Coefficient & T-Statistic & \\
\hline \multirow[t]{7}{*}{ Egypt } & OilRents & 3.41 & $6.70 * *$ & -0.01 & 1.84 & Positive significant \\
\hline & OPP & 2.52 & $5.47 * *$ & -0.03 & 3.69 & Positive significant \\
\hline & GasRents & -0.05 & -0.19 & -0.05 & 2.87 & Negative not significant \\
\hline & Industr & 0.36 & $5.57 * *$ & -0.12 & -4.13 & Positive significant \\
\hline & Lending $R$ & -0.91 & -1.38 & -0.01 & -1.84 & Negative not significant \\
\hline & Tel & 0.12 & $2.39 *$ & -0.18 & -4.47 & Positive significant \\
\hline & Tel100 & 0.12 & $2.20 *$ & -0.16 & -4.45 & Positive significant \\
\hline Nigeria & UrbanPop & 0.21 & $2.34 *$ & -0.37 & -3.70 & Positive significant \\
\hline \multirow[t]{7}{*}{ South Africa } & CPI & -0.00 & -0.12 & -0.51 & -2.48 & Negative not significant \\
\hline & DepositR & 0.18 & 1.24 & -0.15 & -4.45 & Positive not significant \\
\hline & Exports & 0.48 & $3.78 * *$ & -0.16 & -3.52 & Positive significant \\
\hline & GvtCons & 0.87 & $3.10 * *$ & -0.02 & -2.97 & Positive significant \\
\hline & Spread & -0.49 & $-2.25 *$ & -0.02 & 2.57 & Negative significant \\
\hline & GCF & 0.03 & 0.30 & -0.10 & 1.18 & Positive not significant \\
\hline & NetTaxes & -65.01 & $-3.76 * *$ & -0.00 & 1.79 & Negative significant \\
\hline
\end{tabular}

$\mathrm{Y}$, economic growth; LR, long-run; ECM, error correction term; CPI, consumer price index; GCF, gross capital formation; OPP, openness to trade; NBFI, non-bank financial institution; Industr, industrial output; LendingR, lending rate; Tel, number of telephone line connections; Tel100, number of telephone line connections per 100 people; UrbanPop, urban population; DepositR, deposit rate; GvtCons, government consumpotion; Spread, interest rate spread.

$*$, implies significance at $5 \%$; **, implies significance at $1 \%$.

\section{Long-run relationship between non-bank financial institution development and economic growth}

Once the direction of causality has been established using the weak exogeneity test, the next step is to assess the nature (whether positive or negative and the economic significance) of the long-run relationship that exists between NBFI development and economic growth. If causality runs from NBFI development to economic growth, it means economic growth is endogenous. We then normalised on economic growth in order to obtain the effect of the long-run coefficients (elasticities) of NBFI development on economic growth. If the long-run coefficients are positive and significant, this is in the right direction as NBFIs are expected to spur economic growth. Policies must therefore be implemented to strengthen the development and efficiency of the financial sector.

On the contrary, if causality runs from economic growth to NBFI development, it means NBFIs are endogenous. We would therefore need to normalise the model to obtain the effects of the long-run coefficients of economic growth on the development of NBFIs. Positive and economically significant coefficients suggest that the growth of the economy leads to the development of the NBFIs. However, if the evidence shows that the nature of the relationship is weak, it suggests that factors beyond NBFI development and economic growth are at play. In this case, there is urgent need to create an enabling environment to support the development of NBFIs, which, in turn, will stimulate economic growth.

The long-run coefficients and the coefficients of the error correction term (ECM) are presented in Table 4. The coefficients of the ECM describe the 'proportion of disequilibrium from one period that is corrected in the next period' after a shock (Engle \& Granger 1987:254). In this case, a low value of ECM term suggests a low adjustment back to equilibrium after a shock, thus suggesting inefficiencies in the non-banking financial system in facilitating economic growth or rigidities within the economy. Thus, the focus on policy intervention must be to improve efficiency of NBFIs and to reduce rigidities existent within the economy.

The long-run coefficients and the ECM for NBFI development and economic growth are reported separately for the two scenarios: (1) where causality runs from NBFI development to economic growth and (2) where causality runs from economic growth to NBFI development.

\section{Long-run relationship between non-bank financial institution development and economic growth when economic growth is endogenous}

This section presents the long-run parameters and the ECM when causality runs from NBFI development to economic growth. In this case, economic growth is normalised on in the model in order to obtain the elasticity of economic growth in relation to changes in NBFI development. The results are reported in Table 4 .

Egypt: Of the eight models reported for Egypt, six show a positive relationship between NBFI development and economic growth. Five of the six models with a positive effect show that the influence of NBFI development on economic growth is statistically significant at least at a $5 \%$ level of significance, while the remaining model shows that the effect is not significant. The other two models reported a negative effect of NBFI development on economic growth, although such effect is not significant. The long-run coefficients of NBFI development on economic growth range from 0.01 to more than 3.4. This shows that the elasticity of economic growth in response to changes in NBFI development is significant depending on the factors controlled for. Overall, the weight of the evidence shows that the effect of NBFI 
development on economic growth in Egypt is both positive and significant.

In respect of the models that reported a positive and significant effect of NBFI development on economic growth, the three models have the coefficients of the ECM ranging from 0.12 to 0.18 . This shows that on average about $15 \%$ of disequilibria is corrected in a year, thus it would take close to 8 years for full equilibrium to be restored after a shock. The remaining two models with a positive effect have the coefficients of the ECM of 0.01 and 0.03 . On the contrary, the two models that reported a negative effect of NBFI development on economic growth have the coefficients of the ECM between of 0.01 and 0.05 . This evidence suggests that the efficiency of NBFIs in correcting disequilibrium in Egypt is relatively low.

Nigeria: Although the evidence of a relationship between NBFI development and economic growth is weak for Nigeria, the only model reported in Table 4 shows a positive and significant relationship. The model shows that the elasticity of economic growth to changes in NBFI development is 0.21 and the ECM is 0.37 . These results are encouraging as they suggest that the development of NBFIs will spur economic growth.

South Africa: Of the eight models reported for South Africa, five show a positive effect of NBFI development on economic growth, while three show a negative effect. Two of the five models that reported a positive relationship show that the effect of NBFI development on economic growth is significant at a $1 \%$ significance level, while the other three show that the effect is not significant. On the contrary, of the three models that reported a negative effect, two show that the effect of NBFI development on economic growth is significant at $1 \%$ and 5\% significance levels. However, the model that is significant at $1 \%$ reported an unusually high elasticity of more than one (65) and a zero coefficient of the ECM. If we discount the model with the extreme elasticity, the weight of the evidence would suggest that the effect of NBFI development on economic growth in South Africa is positive.

The coefficient of the ECM for South Africa ranges between 0.02 and 0.16 for models that reported a positive and significant relationship between NBFI development and economic growth. This shows that there is need to improve the efficiency of the NBFIs if South Africa is to fully capitalise on the economic benefits emanating from the development of NBFIs.

\section{Long-run relationship between non-bank financial institution development and economic growth when non-bank financial institution development is endogenous}

This section presents the long-run parameters and the ECM when causality runs from economic growth to NBFI development. In this case, NBFI development is normalised in the model in order to obtain its elasticity in relation to changes in economic growth. We present the results in Table 5.

Egypt: Four of the six models reported for Egypt show that economic growth positively influences the development of NBFIs, and significantly so. On the contrary, the remaining two models show a negative effect of economic growth on NBFI development, of which one model shows that the effect is significant. The elasticities of NBFI development to changes in economic growth are more than one for all the six models reported. This shows that growing the economy will generate far more growth in the financial sector, which should in turn influence economic growth as demonstrated above.

In addition, the results also show that the coefficient of the ECM for Egypt is between 0.01 and 0.11 . This is reflective of possible rigidities within the Egyptian economy. Accordingly, in order to realise greater development of the financial sector as the economy grows, policies should be put in place to minimise rigidities that may exist within the economy.

Overall, the evidence in Egypt suggests that a virtuous cycle exists, wherein NBFI development and economic growth are mutually reinforcing each other.

Nigeria: Although the results presented in Table 5 show that the effect of economic growth on the development of NBFIs is positive, such effect is not significant and the evidence is weak. The elasticity of NBFI development to changes in economic growth is 0.74 and the ECM is 0.22 .

South Africa: When NBFIs is endogenous, only one model shows that the effect of economic growth on the development of

TABLE 5: Long-run parameters of models with causality running from economic growth to non-bank financial institutions.

\begin{tabular}{|c|c|c|c|c|c|c|}
\hline \multirow[t]{2}{*}{ Country } & \multirow[t]{2}{*}{ Control variable } & \multicolumn{2}{|c|}{ LR coefficient of $Y$ on NBFI } & \multicolumn{2}{|c|}{ ECM } & \multirow[t]{2}{*}{$Y \rightarrow N B F I$ (Sign of effect) } \\
\hline & & Coefficient & T-Statistic & Coefficient & T-Statistic & \\
\hline \multirow[t]{6}{*}{ Egypt } & GasRents & -20.65 & $-3.14^{* *}$ & -0.10 & 1.97 & Negative significant \\
\hline & Industr & 2.78 & $12.60 * *$ & -0.11 & -1.61 & Positive significant \\
\hline & LendingR & -1.10 & -0.23 & -0.09 & -3.19 & Negative not significant \\
\hline & NetTaxes & 69.91 & $4.60 * *$ & -0.01 & -2.44 & Positive significant \\
\hline & Tel & 8.12 & $5.77 * *$ & -0.11 & -3.77 & Positive significant \\
\hline & Tel100 & 8.07 & $5.72 * *$ & -0.10 & -3.75 & Positive significant \\
\hline Nigeria & GasRents & 0.74 & 0.50 & -0.22 & -3.80 & Positive not significant \\
\hline \multirow[t]{2}{*}{ South Africa } & GCF & 42.60 & $2.27 *$ & -0.02 & 3.05 & Positive significant \\
\hline & NetTaxes & -0.02 & -0.05 & -0.61 & 2.68 & Negative not significant \\
\hline
\end{tabular}

ECM, error correction term; GCF, gross capital formation; NBFI, non-bank financial institution; Y, economic growth; LR, long-run; Industr, industrial output; LendingR, lending rate; Tel, number of telephone line connections; Tel100, number of telephone line connections per 100 people.

$*$, implies significance at $5 \% ; * *$, implies significance at $1 \%$. 
TABLE 6: Summary of findings in respect of the relationship between non-bank financial institutions and economic growth in Egypt, Nigeria and South Africa.

\begin{tabular}{|c|c|c|}
\hline Country & $\begin{array}{l}\mathrm{Y} \leftarrow \mathrm{NBFI} \text { (Effect NBFI on } \\
\text { economic growth) }\end{array}$ & $\begin{array}{l}Y \rightarrow \text { NBFI (Effect economic } \\
\text { growth on NBFIs) }\end{array}$ \\
\hline Egypt & Positive significant & Positive significant \\
\hline Nigeria & Positive & Positive not significant \\
\hline South Africa & Positive significant & Positive \\
\hline
\end{tabular}

$\mathrm{NBFI}$, non-bank financial institution; $\mathrm{Y}$, economic growth.

NBFIs in South Africa is both significant and positive. Although weak, the evidence suggests that the relationship between NBFI development and economic growth in South Africa is predominantly supply-leading, as discussed above.

Lastly, we show in Table 6 the summary of findings from this article on the relationship between NBFIs and economic growth. Ultimately, the results show that there is a positive long-run relationship between NBFI and economic growth.

\section{Conclusion}

This article investigates the long-run relationship between NBFI development and economic growth in Egypt, Nigeria and South Africa - the three largest African economies. The study employs the Johansen cointegration and error correction modelling framework within a country-specific setting. The results of the study can be summarised as follows: Firstly, cointegration tests reported in this article show the existence of a long-run relationship between NBFI development and economic growth in Egypt and South Africa. Evidence of such a relationship in Nigeria is weak, as only two models (out of a possible 22) were reported. These findings are in line with previous empirical studies, which also found that countries with relatively more developed financial systems exhibit evidence of a long-run relationship between NBFI development and economic growth (Cheng \& Degryse 2007; Haiss \& Sumegi 2008; Meng \& Pfau 2010).

Secondly, the direction of causality between NBFI development and economic growth in Egypt is predominantly bidirectional, while such relationship in South Africa predominantly runs from NBFI development to economic growth. The relationship is generally both positive and significant in the two countries. Thus, in Egypt, the evidence suggests a virtuous cycle in the relationship between NBFI development and economic growth, while in South Africa, NBFI development appears to be supply-leading phenomenon. The relatively stronger results in Egypt and South Africa, compared with Nigeria, are not surprising, given the level of development of NBFIs in South Africa and Egypt. The two countries have arguably the most developed financial systems in Africa. To this end, well-developed NBFIs are expected to mobilise savings and provide mechanisms for risk management and efficient allocation of capital, thus enhancing economic growth.

Thirdly, the coefficients of the ECM for all three countries suggest inefficiencies in the three countries' financial systems and rigidities within their economies. Specifically, the ECM reported very low values (sometimes close to zero), which suggest that shocks emanating from either the economy or the financial system may not be quickly corrected to restore full equilibrium.

As indicated above, there is a dearth of studies investigating the relationship between NBFIs and economic growth in Africa. To the best of our knowledge, this study is the first one which uses the Johansen cointegration and vector error correction model covering such a long period (1971-2013). Therefore, the results from our article significantly add to the literature and provide useful insight to policy-makers on the potential of NBFIs to stimulate economic growth in the respective countries.

On the basis of the empirical results discussed above, the following suggestions emerged for policy consideration in each of the countries.

\section{Egypt}

It is suggested that policies be developed and implemented to improve efficiency of the financial system. This will enable the Egyptian financial system to efficiently carry out its intermediation role. More efficient intermediation is likely to enhance economic growth, given the existence of significant positive causal link between NBFI development and economic growth.

\section{Nigeria}

Weak evidence of long-run causality between NBFI development and economic growth in Nigeria suggests that factors exogenous to the finance-growth nexus may be at play. In this regard, it is suggested that relevant policies be developed to create an enabling environment which supports the development of the financial sector and growth of the economy. Once growth of the economy reaches a certain threshold, both systems may start reinforcing each other, thereby resulting in a positive relationship. Specific emphasis may be put on improving the legal systems to guarantee property right as well as improving infrastructure such as roads and electricity. It is also necessary to diversify the economy to put less emphasis on the petroleum sector.

\section{South Africa}

Based on the low coefficient of the ECM, we suggest that financial sector policies focus on improving the efficiency of NBFIs in carrying out their financial intermediary role in that country.

Therefore, given that traditional bank lending has declined while NBFIs have emerged as a potential source of long-term capital, results from this study should be invaluable to policy formulation pertaining to the importance and development of NBFIs. However, the weak results maybe emanating from the weak regulatory framework prevailing in most African countries, resulting in NBFIs weakly contributing to economic growth. Therefore, there is a need to improve the regulatory systems to prevent excessive growth and risk appetite by NBFIs, which may have catastrophic consequences in some cases. 


\section{Acknowledgements}

The authors would like to thank Prof. Cornelia Pop and the two anonymous reviewers for their comments and guidance in drafting this article.

\section{Competing interests}

The authors declare that they have no financial or personal relationships that may have inappropriately influenced them in writing this article.

\section{Authors' contributions}

R.R. was responsible for data gathering, analysis and providing the initial draft. M.J.A was responsible for designing the econometric framework for the analysis, overseeing the empirical analysis and interpretation of the results as well as general review of the article.

\section{References}

Alderman, H. \& Yemtsov, R., 2013, How can safety nets contribute to economic growth? Volume Working Paper 6437, World Bank, Washington, DC.

Arestis, P., Luintelc, A.D. \& Luintel, K.B., 2010, 'Financial structure and economic growth: Evidence from time series analyses', Applied Financial Economics 20, 479-1492. https://doi.org/10.1080/09603107.2010.508716

Aziakpono, M.J., 2008, 'The depth of financial integration and its effects on financial development and economic performance of the SACU countries', PhD thesis, University of Free State, Bloemfontein.

Aziakpono, M.J., 2011. 'Financial development and economic growth: Theory and a survey of evidence', Journal for Studies in Economics and Econometrics 35(1), 15-43,

Berthelemy, J.C. \& Varoudakis, A., 1996, 'Economic growth, convergence clubs, and the role of financial development', Oxford Economic Papers 48, 300-328. https:// doi.org/10.1093/oxfordjournals.oep.a028570

Brooks, C., 2014, Introductory econometrics of finance, 3rd edn., Cambridge University Press, Cambridge.

Central Bank of Egypt, 2015, Publications, accessed on 16 June 2015 from http://www. cbe.org.eg/en/EconomicResearch/Publications/Pages/MonthlyStatisticaclBulletin. aspx

Central Bank of Nigeria, 2015, Data and Statistics, accessed on 15 June 2015 from https://www.cbn.gov.ng/documents/data.asp

Cheng, X. \& Degryse, H., 2007, The impact of bank and non-bank financial institutions on local economic growth in China, Volume Discussion Paper 22, Bank of Finland: Institute for Economies in Transition, Helsinki.

Davis, P. \& Hu, Y.-W., 2008, 'Does funding of pensions stimulate economic growth?' Journal of Pension Economics and Finance 7(2), 221-249. https://doi.org/10.1017/ S1474747208003545

Demetriades, P.O. \& James, G., 2011, Finance and growth in Africa: The broken link, Working Paper11(17), University of Leicester, Liecester.

Demetriades, P.O. \& Rousseau, P.L., 2015, The changing face of financial development Working Paper (15/20), University of Leicester, Liecester.

Egyptian Financial Supervisory Authority, 2017, Non-banking financial markets, viewed 19 February 2017, from http://www.efsa.gov.eg/content/efsa_en/efsa pages_en/main_efsa_page_en.htm

Engle, R.F. \& Granger, C.W.J., 1987, 'Co-integration and error correction Representation, estimation, and testing', Econometrica 55(2), 251-276. https:// doi.org/10.2307/1913236

Faure, P., Gidlow, R., Goodspeed, I., Hodge, D., Ketola, R., Kock, M. et al., 2006 Understanding South African financial markets, Van Schaik, Pretoria.

Financial Stability Board, 2015, Global shadow banking monitoring report, Financial Stability Board, Basel.

Geda, A., Ngungu, N. \& Zerfu, D., 2012, Applied time series econometrics: A practical guide to macroeconomic reserachers with a focus on Africa, Univeristy of Nairobi Press, Nairobi.

Haiss, P. \& Sumegi, K., 2008, 'The relationship between insurance and economic growth in Europe: A theoretical and empirical analysis', Empirica 35, 405-431. https://doi.org/10.1007/s10663-008-9075-2
Hamdi, A.R., 2015, Financing Africa's extractive industries: The role of banks and nonbank financial institutions - The example of Sudan, UNCTAD, Geneva.

Holzmann, R., 1997, 'Pension reform, financial market development and economic growth: Preliminary evidence from Chile', International Monetary Fund 44(2), 149-178. https://doi.org/10.2307/3867541

International Monetary Fund, 2015a, Financing for development: Revisiting the monterrey consensus, IMF, Washington, DC.

International Monetary Fund, 2015b, International Financial Statistics, IMF, Washington, DC

Kabia, A.B., Conteh, B.K. \& Jalloh, A.A.A., 2015, 'The complementary role of non-bank financial institutions in Siera Leone financial intermediary space: A case study of National Cooperative Development Bank', International Journal of Economics, Commerce and Management III(4), 1-36.

Kennedy, P., 2003, A guide to econometrics, 5th edn., Blackwell Publishers Ltd, Oxford.

KPMG Africa Limited, 2013, Financial services in Africa report, KPMG Africa Limited, Johannesburg.

Levine, R., 2004, Finance and growth: Theory and evidence, Working Paper 10777, National Bureau of Economic Research, Cambridge, MA.

Levine, R. \& Servos, S., 1998, 'Stock markets, banks, and economic growth', The American Economic Review 88(30), 537

Liang H.-Y. \& Reichert, A.K., 2012, 'The impact of banks and non-bank financial institutions on economic growth', The Service Industries Journal 35(5), 699-717. https://doi.org/10.1080/02642069.2010.529437

Luintel, K.B. \& Khan, M., 1999, 'A quantitative reassessment of the finance-growth nexus: Evidence from a multivariate VAR', Journal of Development Economics 60, 381-405. https://doi.org/10.1016/S0304-3878(99)00045-0

Meng, C. \& Pfau, W.D., 2010, 'Role of pension funds in capital market development', National Graduate Institute for Policy Studies 10(17), 1-21.

Mishkin, F., 2007, The economics of money, banking and financial markets, Pearson Education, Toronto.

Mo Ibrahim Foundation, 2013, Africa ahead: The next fifty years, Mo Ibrahim Foundation, Addis Ababa.

Nassr, I.K. \& Wehinger, G., 2014, 'Non-bank debt financing for SMEs: The role of securitisation, private placements and bonds', OECD Journal: Financial Market Trends 2014(1), 139-159.

Ndugbu, M.O., Ojiegbe, J., Uzowuru, B.L. \& Okere, P.A., 2015, 'Bank and non-bank financial institutions and the development of the Nigerian economy', International Journal for Innovation Education and Research 3(8), 23-36.

Ofoeda, I., Gariba, P. \& Amoah, L., 2016, 'Regulation and performance of non-bank financial institutions in Ghana', International Journal of Law and Management 58(1), 108-125. https://doi.org/10.1108/IJLMA-11-2014-0060

Osuala, A. \& Odunze, C.O., 2014, 'Do non-bank financial institutions' loans and advances influence economic growth? A bounds test investigation', European Journal of Business and Management 6(27), 11-15.

Patrick, H.T., 1966, 'Financial development and economic growth in underdeveloped countries', Economic Development and Cultural Change 14(2), 174-189. https:// doi.org/10.1086/450153

Rousseau, P.L. \& Wachtel, P., 2011, 'What is happening to the impact of financial deepening on economic growth?' Economic Enquiry 49(1), 276-288. https://doi. org/10.1111/j.1465-7295.2009.00197.x

South African Reserve Bank, 2015, Online Statistics, accessed on 16 June 2015 from https://www.resbank.co.za/Research/Statistics/Pages/OnlineDownloadFacility. aspx

Sufian, F. \& Majid, M.-Z.A., 2009, 'Post-crisis productivity change in non-bank financial institutions: Efficiency increase or technological progress?' Journal of Transnational Management 14, 124-154. https://doi.org/10.1080/15475770903028381

United Nations Statistics, 2015, International Trade Statistics Yearbook, United Nations Publication, New York.

Vittas, D., 1997, The role of non-bank financial intermediaries in Egypt and other MENA countries, World Bank Development Research Group, Washington, DC.

World Bank, 2013a, Financing for development, post 2015, World Bank, Washington, DC.

World Bank, 2013b, Global Development Finance Database, World Bank, Washington, DC.

World Bank, 2015a, Global financial development report: Long term finance, World Bank, Washington, DC

World Bank, 2015b, s.n, s.l., viewed 19 November 2015, from http://data.worldbank. org/data-catalog/GDP-ranking-table

World Bank, 2015c, Key terms explained, viewed 19 November 2015, from http:// econ.worldbank.org/wbsite/external/extdec/extglobalfinreport/0,,contentMDK: 23268764 pagePK:64168182 piPK:64168060 theSitePK:8816097,00.html

World Bank, 2015d, World Development Indicators, World Bank, Washington, DC.

Yeh, C.-C., Huang, H.-C. \& Lin, P.-C., 2013, 'Financial structure on growth and volatility', Economic Modelling 35, 391-400. https://doi.org/10.1016/j.econmod.2013.07.034 